\title{
GEOARCHAEOLOGICAL INVESTIGATION AT THE BUFFALO RANCH SITE (41BU119), TEXAS
}

\author{
An Undergraduate Research Scholars Thesis \\ by
}

ANALISE HOLLINGSHEAD

\begin{abstract}
Submitted to the Undergraduate Research Scholars program at Texas A\&M University

in partial fulfillment of the requirements for the designation as an
\end{abstract}

UNDERGRADUATE RESEARCH SCHOLAR

Approved by Research Advisor:

Dr. Michael R. Waters

May 2017

Major: Anthropology 


\section{TABLE OF CONTENTS}

Page

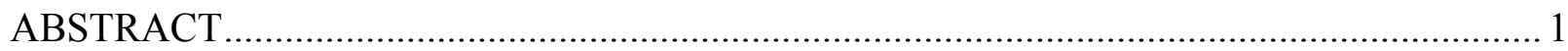

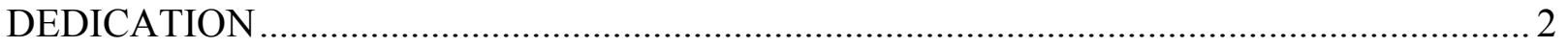

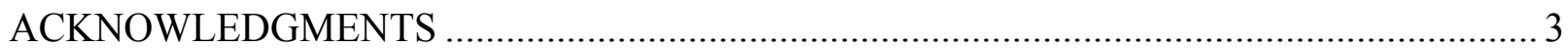

\section{CHAPTERS}

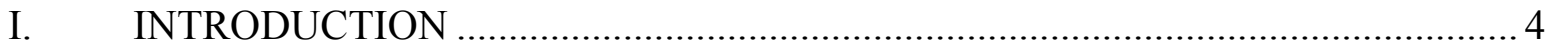

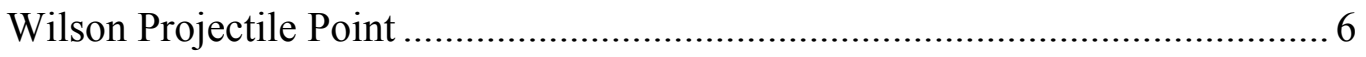

Big Sandy Projectile Point ........................................................................ 10

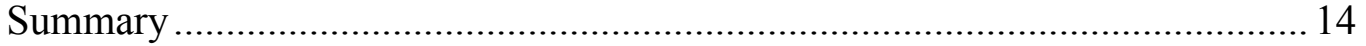

II. THE BUFFALO RANCH SITE (41BU119) .............................................. 15

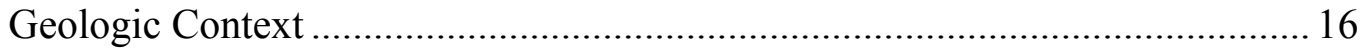

Archaeological Investigation at the Buffalo Ranch Site (41BU119)................ 22

Radiocarbon Dating ........................................................................ 24

CONCLUSION

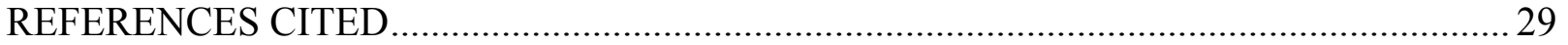




\begin{abstract}

\author{
Analise Hollingshead \\ Department of Anthropology \\ Texas A\&M University \\ Research Advisor: Dr. Michael R. Waters \\ Department of Anthropology \\ Texas A\&M University
}

Geoarchaeological Investigation at the Buffalo Ranch Site (41BU119), Texas

The Buffalo Ranch site (41BU119) is located along the Brazos River in Burleson County, Texas under $11 \mathrm{~m}$ of late Quaternary alluvium. Here, a Wilson projectile point and Big Sandy projectile point, along with other artifacts, were found in natural levee sediments. Two radiocarbon ages place this site between 9605 to 9545 cal yr B.P. The Buffalo Ranch site is the first locality in Texas and the American Southeast where these two points co-occur, and adds to our understanding of the late Pleistocene-early Holocene transitional period of this region. 


\section{DEDICATION}

I would like to dedicate this to my parents, William and Jennifer Hollingshead. You have inspired me to always work hard, no matter the journey. I will always be, "your little archaeologist". 


\section{ACKNOWLEDGMENTS}

I would like to thank Dr. Michael Waters for granting me the opportunity to work on this project. I would also like to thank him for mentoring me the past four years through my journey at Texas A\&M, providing valuable opportunities to further explore my career as an archaeologist. I would also like to thank Dr. Britt Bousman at Texas State University for sharing his experience and materials with me from earlier investigations of the Buffalo Ranch site. I would also like to thank Steven Dunbar and the rest of Buffalo Ranch for allowing me to continually visit the property in order to carry out this investigation, and protecting my fellow field assistants and I when a wild hog-dog was on the loose.

I would also like to thank the Department of Anthropology, the George Bush Presidential Library Foundation, and the College of Liberal Arts for providing funds necessary to complete this investigation. The Center for Study of First Americans also provided equipment and laboratory space necessary to complete this project.

I would also like to thank Dr. Joshua Keene for providing much needed advice and guidance throughout this project, both in the field and in the lab. I would also like to thank him for always encouraging me to press forward, no matter the obstacles in the way.

I would like to thank Dr. Waters's geoarchaeology class members for their assistance in geologic interpretations of the site. Finally, I would like to thank my excavation crew: Daniel Welch, Anna Dean, Morgan Smith, and Bucky. 


\section{CHAPTER I}

\section{INTRODUCTION}

During the time period from the end of the Pleistocene through the early Holocene, people were adapting to environmental changes across the landscape, and responding to these changes through cultural adaptations (Bousman and Vierra 2012). One important adaption marking this period is the change in lithic technologies. People who originally manufactured lanceolate projectile points started producing stemmed projectile points during this transitional period.

The earliest stemmed projectile point types found in the American Southeast are Wilson and Big Sandy. Wilson projectile points are exclusively found in Texas, while Big Sandy projectile points are found throughout the American Southeast, including Texas. While we can recognize this transition by the appearance of Wilson and Big Sandy projectile points, the age of this transition is poorly known. Bousman and Oksanen (2012) suggest this transitional period occurred in Texas between 11,650 and 9050 cal yr B.P.

In this thesis, I first review the geochronological evidence for Wilson and Big Sandy points. This is followed by the results of my excavations at the Buffalo Ranch site (41BU119), where both Wilson and Big Sandy points were found. I present two new radiocarbon ages from this site that provide chronological information about these poorly dated types. 


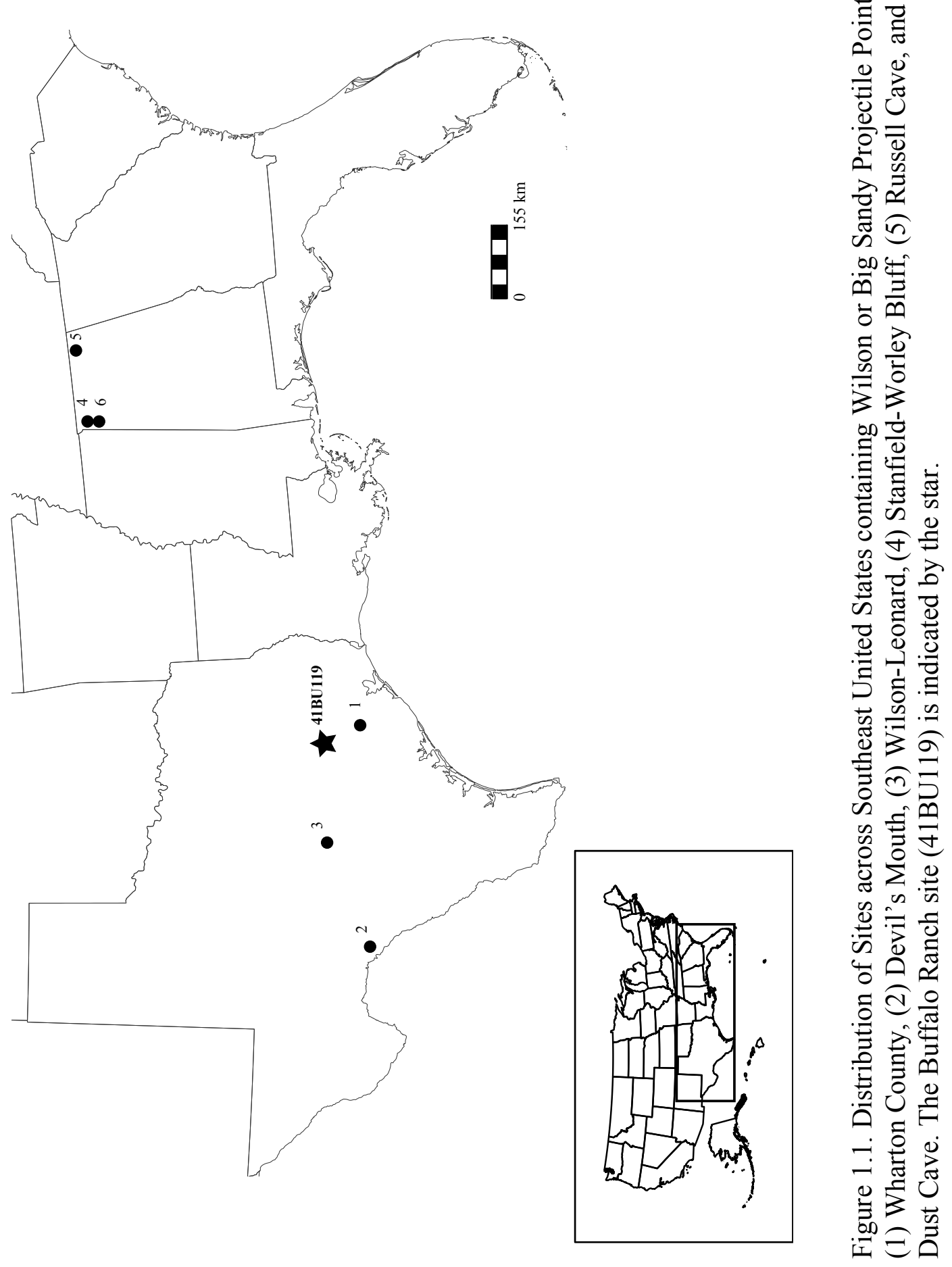

5 


\section{Wilson Projectile Point}

The Wilson projectile point is a corner-notched projectile form with a thick, expanding stem with basally ground edges, and random bifacial flake patterns along the blade (Collins 1998). Wilson, or similar Early Stemmed projectile points, have been recovered from nineteen sites across Central and South Texas (Collins 1998; Bousman and Oksanen 2012). Only three of these sites have Wilson points that come from a buried geologic context with radiocarbon dates. Here, I evaluate the geochronological evidence at Wharton County, Devil's Mouth, and WilsonLeonard sites.
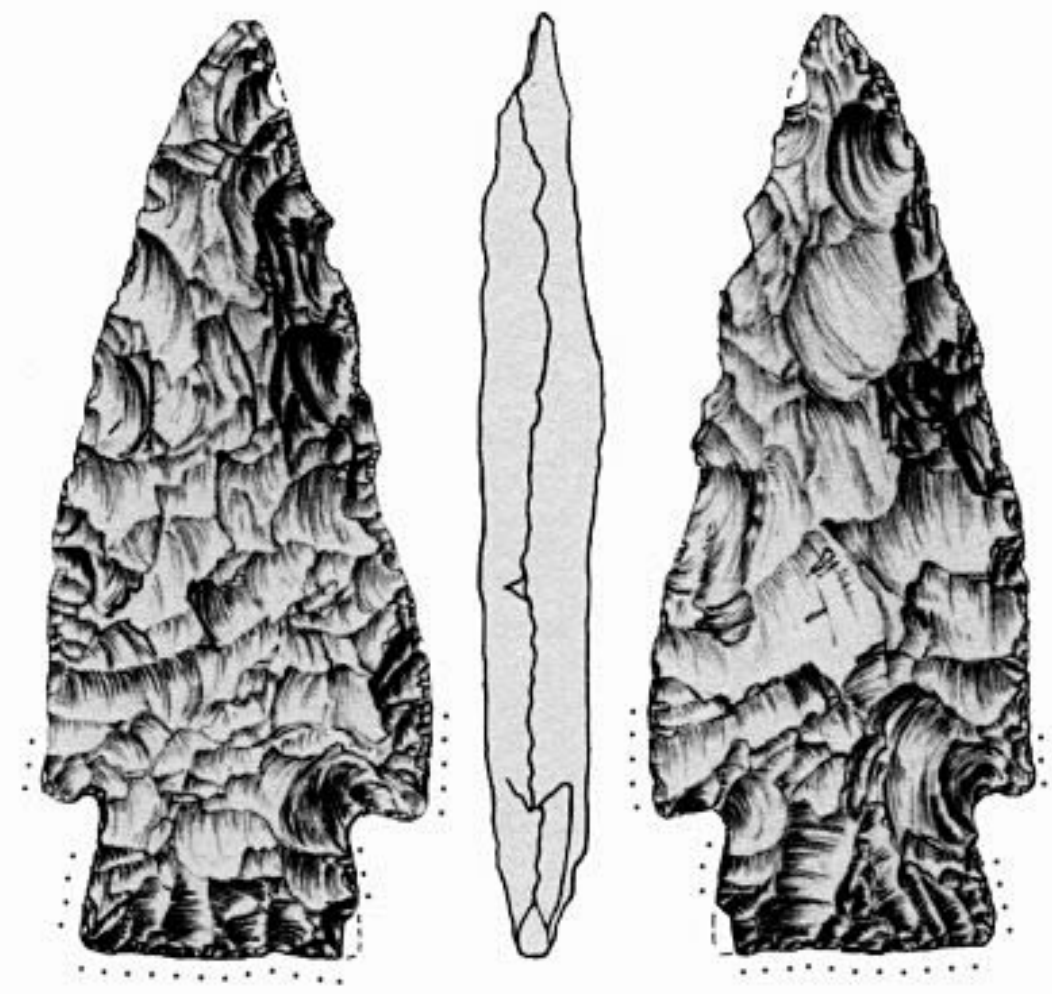

Figure 1.2. Typical Wilson projectile point (Collins 1998). Dots indicate areas of grinding along the haft element. 
Wharton County Site (41WH19), Texas

Here, Patterson and Hudgins (1985) found one Wilson point in Stratum 4, in association with a Folsom projectile point base. This suggests either a possible association of these two projectile point styles, or the archaeological components are mixed at this site. Based on this stratigraphic context, Patterson and Hudgins (1985) suggested the Wilson point co-occurred with Folsom. One radiocarbon date of $9920 \pm 530{ }^{14} \mathrm{C}$ yr B.P. (AA-298) (Patterson and Hudgins 1985) was obtained on a small piece of charcoal recovered during screening of the lower half of Stratum 4 (Table 1.1). Its exact provenience in relation to the Wilson and Folsom projectile point is unknown. Calibration of the radiocarbon age is between 12,175 and 10,700 cal yr B.P., just barely overlapping the age of Folsom (12,200 and 12,700 cal yr B.P.). This single age does not provide a reliable date for Wilson points, because of the poor provenience of the charcoal sample and large standard deviation associated with the date, which resulted in a wide calibrated age range.

\section{Devil's Mouth Site, Texas}

Devil's Mouth is located in southern Val Verde County, 19 km northwest of Del Rio, Texas. Here, Johnson (1962) recovered Early Stemmed projectile points, morphologically similar to Wilson projectile points, from a gravel deposit referred to as 'Upper Gravels' in Area $\mathrm{C}$ of the site. In this same gravel deposit, Johnson also found two Angostura and two Golondrina projectile points (Sorrow 1968; Bousman et. al 2004). In a later excavation, Sorrow (1968) found four more Wilson projectile points in Stratum P from Bench 2 in Area D. A piece of dispersed charcoal from this deposit dated to $8780 \pm 310{ }^{14} \mathrm{C}$ yr B.P. (Tx-556) (Sorrow 1968). Calibrated, 
this age yields a range from 10,231 to $9504 \mathrm{cal}$ yr B.P. This date is of limited use in defining the age of Wilson, because of poor provenience of the charcoal sample and large standard deviation.

\section{Wilson-Leonard Site, Texas}

Wilson-Leonard is a multi-component site located in Williamson County, Texas along Brushy Creek, a tributary of the Brazos River (Collins 1998; Bousman et. al 2002). There, Collins defines a cultural horizon he calls, "The Wilson zone," in stratigraphic units Isi-c and Id. Here, he found nine Wilson points with two Golondrina-Barber points and other artifacts (Collins 1998). Five radiocarbon dates for Unit Isi-c range from $9410 \pm 60{ }^{14} \mathrm{C}$ yr B.P. (CAMS14805) to $9990 \pm 70{ }^{14} \mathrm{C}$ yr B.P. (CAMS-10195; Table 1.1). This yields a calibrated age range from 11,610 to 10,570 cal yr B.P. Collins (1998) assigns this "Wilson zone" to the late Paleoindian time period.

Nine Wilson points were also found in stratigraphic Unit II, overlying Unit I, but these points are mixed with many different types. From Unit II, ten Golondrina-Barber, one Midland, one Scottsbluff, one San Patrice, one Big Sandy, four St. Mary's Hall, two Angostura, six unidentifiable lanceolate, and four Early Archaic projectile points were found with the Wilson projectile points (Collins 1998). Radiocarbon dates from Unit II range from $8830 \pm 90{ }^{14} \mathrm{C} \mathrm{yr}$ B.P. (CAMS-10207) to $9650 \pm 80{ }^{14} \mathrm{C}$ yr B.P. (CAMS-7560), or 11,186 to $9709 \mathrm{cal}$ yr B.P. While Collins (1998) accepts the radiocarbon ages from Unit II, he feels that the archaeological contexts in this unit are mixed. 


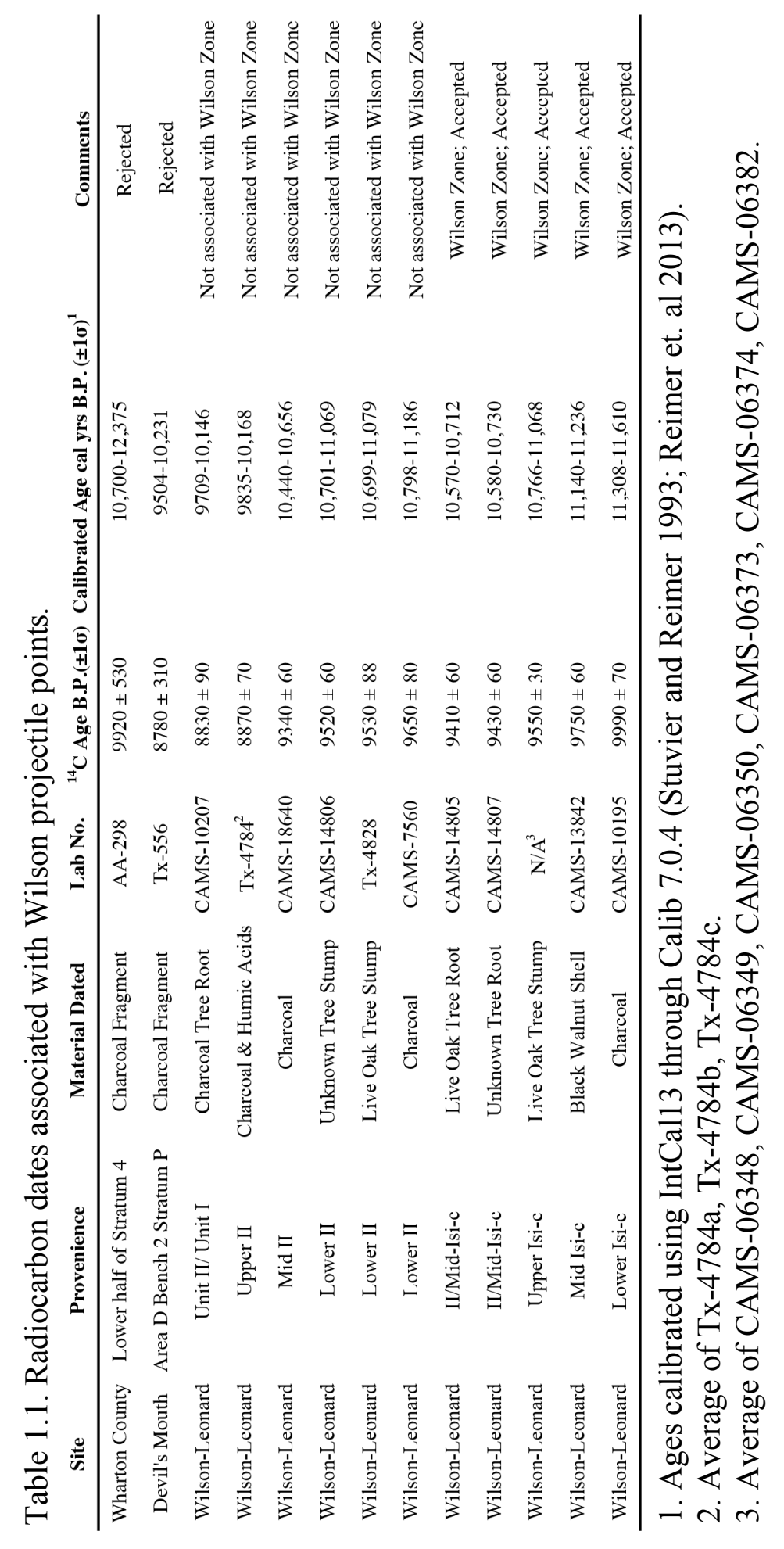




\section{Big Sandy Projectile Point}

Big Sandy projectile points are small to medium stemmed points with a squared base, distinct side notches, and a narrow, triangle shape as the blade, with no edge grinding (Kneburg 1956; Justice 1987; Cambron and Hulse 1975). This projectile point was defined by Kneberg (1956) at the Big Sandy site located along the Big Sandy tributary in Tennessee.

Big Sandy projectile points are found in dated, stratified contexts at four archaeological sites in Texas and the Southeastern United States. Here, I evaluate the geochronological evidence at Stanfield-Worley Bluff, Russell Cave, Dust Cave, and the Wilson-Leonard site.

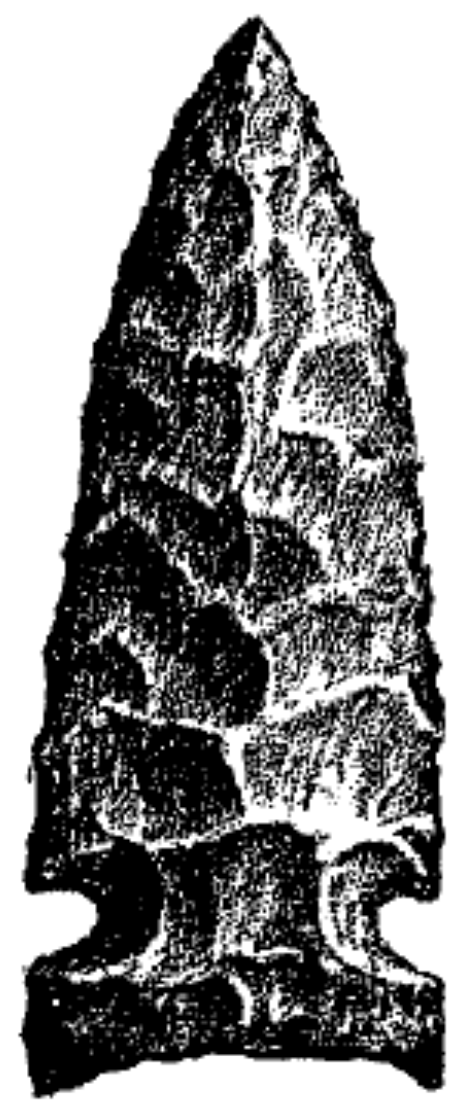

Figure 1.3. Typical Big Sandy projectile point (Kneberg 1956). 
Stanfield-Worley Bluff Site, Alabama

Stanfield-Worley Bluff is a stratified rockshelter in Colbert County, Alabama (DeJarnette et. al 1962). Fifty Big Sandy, thirty Dalton, four Hardaway side-notched, three Greenbriars, three Stanfield triangulars, one Beaver Lake, and seven stemmed projectile points were found in the lowest zone of this site, Zone D (Goodyear 1982). Five radiocarbon dates are associated with this layer and range in age from $8920 \pm 400{ }^{14} \mathrm{C}$ yr B.P. (M-1153) to $9640 \pm 450{ }^{14} \mathrm{C}$ yr B.P. (M1152), or 11,701 to 9527 cal yr B.P. (Crane and Griffin 1965; DeJarnette 1962). Based on the lithic evidence, Dejarnette (1962) classifies Zone D as a surface containing late Paleoindian and Early Archaic components, resembling a transitional period between these two components. Goodyear (1982) does not feel the ages from Zone D are associated with Big Sandy projectile points because the relationship between the dates and the artifacts is poorly documented, and the large standard deviation of the ages lack precision.

\section{Russell Cave Site, Alabama}

Russell Cave is a stratified rockshelter located in Jackson County, Alabama (Griffin 1974). Three Big Sandy projectile points were recovered from Layer G, along with one Flint Creek, one Kirk Corner Notched, one Pine Tree, two Kirk serrated, three Lecroy, and eight Russell Cave projectile points (Griffin 1974). Five dispersed charcoal samples from Layer G provided radiocarbon ages ranging from $7565 \pm 250{ }^{14} \mathrm{C}$ yr B.P. (I-2237) to $8500 \pm 320{ }^{14} \mathrm{C}$ yr B.P. (I-2239). Calibrated, the dates range from 9910 to $8049 \mathrm{cal}$ yr B.P. and are considered to date the Big Sandy projectile point style. 


\section{Dust Cave Site, Alabama}

Dust Cave is a stratified, multicomponent rockshelter located in Lauderdale County, Alabama. Forty-three Early Side Notched projectile points were found in Zone R of Dust Cave, a zone containing prepared surfaces and small pits (Sherwood et. al 2004). Collins (1998) believes that these points closely resemble the Big Sandy point found at the Wilson-Leonard site. One heavily resharpened Dalton projectile point was also found in this same deposit (Sherwood et. al 2004).

One charred sample was collected from Zone R. This sample yielded an age of 10,070 \pm $60{ }^{14}$ C yr B.P. (Beta-81602), or 11,950 to 10,950 cal yr B.P. Thulman (2017) completed a Bayesian analysis of the dates from Dust Cave, and provided a revised age for the Early Side Notched component of 11,450 to $10,950 \mathrm{cal}$ yr B.P. This may provide a reliable age for the Big Sandy projectile point style. However, it should be cautioned that this age is based on a single radiocarbon sample of dispersed charred material in Zone R. Also, it is much older than most dates from other sites with Big Sandy projectile points.

\section{Wilson-Leonard Site, Texas}

One Big Sandy projectile point was found in stratigraphic Unit II in association with nine Wilson projectile points, five Golondrina-Barber, one Scottsbluff, one San Patrice, four St. Mary's Hall, two Angostura, three unidentifiable lanceolate, and four Early Archaic projectile points (Collins 1998). Ages for Unit II are reported in Table 1.1. However, as noted earlier, Bousman and others (2002) believe the archaeological context of Unit II is mixed. The ages range from $8830 \pm 90{ }^{14} \mathrm{C}$ yr B.P. (CAMS-10207) to $9650 \pm 80{ }^{14} \mathrm{C}$ yr B.P. (CAMS-7560), or 11,186 to 9709 cal yr B.P. 


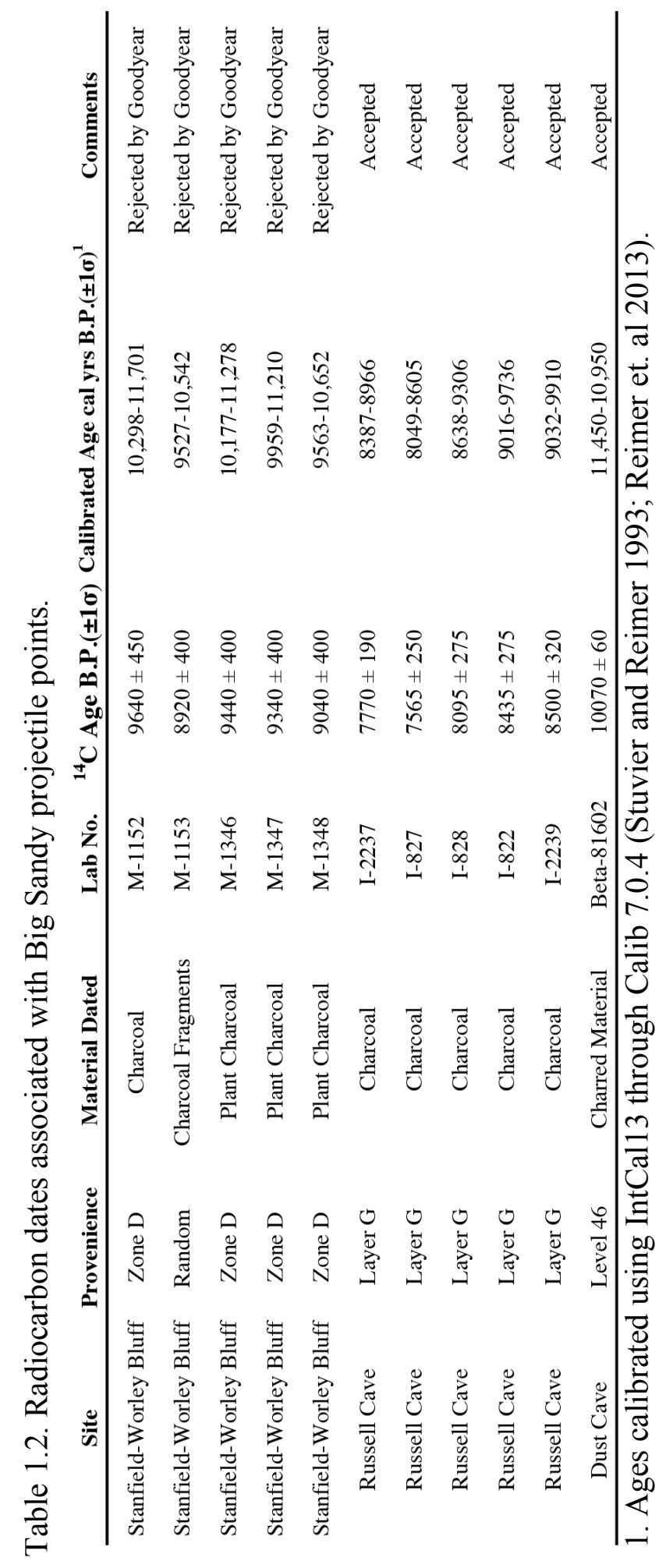




\section{Summary}

While a number of dated sites have yielded Wilson projectile point styles, the WilsonLeonard site in Texas provides the only secure age for this type. The age for the "Wilson zone" at this site ranges from 11,610 to 10,570 cal yr B.P., currently the only ages associated with the Wilson projectile point.

Similarly, the Big Sandy projectile point type is poorly dated. Only one radiocarbon age from Dust Cave, 11,450 to 10,950 cal yr B.P, and five radiocarbon ages from Russell Cave, ranging from 9910 to 8049 cal yr B.P, provide reliable ages for this type. 


\section{CHAPTER II}

\section{THE BUFFALO RANCH SITE (41BU119)}

The Buffalo Ranch site (41BU119) is located on the northern edge of Burleson County, Texas. The site is buried $11 \mathrm{~m}$ below the surface at the base of a cutbank along the Brazos River. Here, one Wilson and Big Sandy projectile point were found out of context by Michael Waters (personal communication 2015) in 2012. Waters determined that these projectile points had recently eroded from an archaeological site exposed in the cutbank. Another survey was conducted in 2014 by Britt Bousman (personal communication 2015). He collected lithic tools, flakes, fire-cracked rocks, and bones eroded from the same archaeological layer.

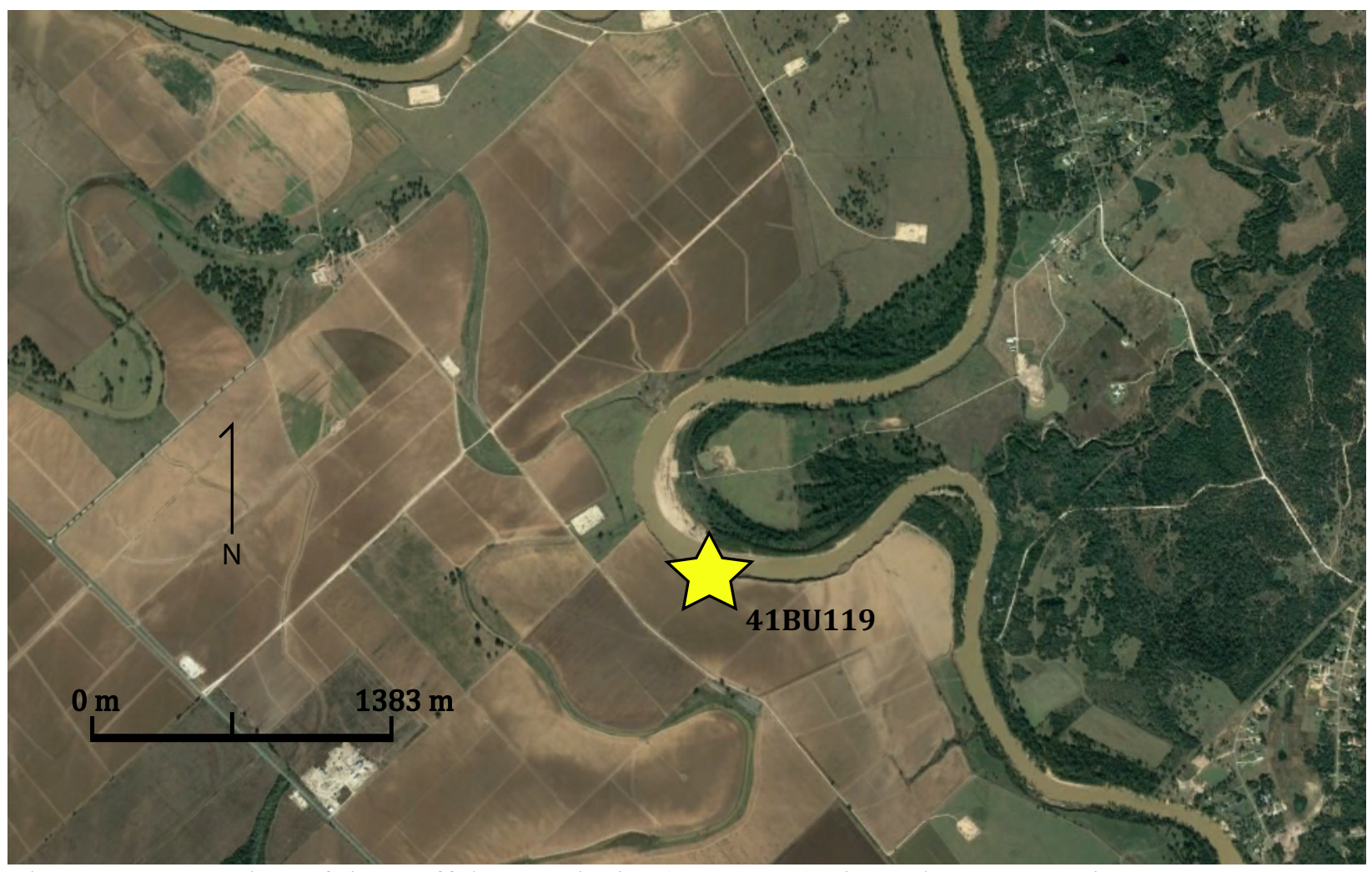

Figure 2.1. Location of the Buffalo Ranch site (41BU119) along the Brazos River. 
The Buffalo Ranch site (41BU119) is important because it is the first site in the American Southeast where Wilson and Big Sandy projectile points co-occur in undisturbed geologic deposits. I returned to 41 BU119 to place the artifacts, specifically these projectile points, in a stratigraphic context and collect samples for radiocarbon dating in order to securely date this archaeological horizon.

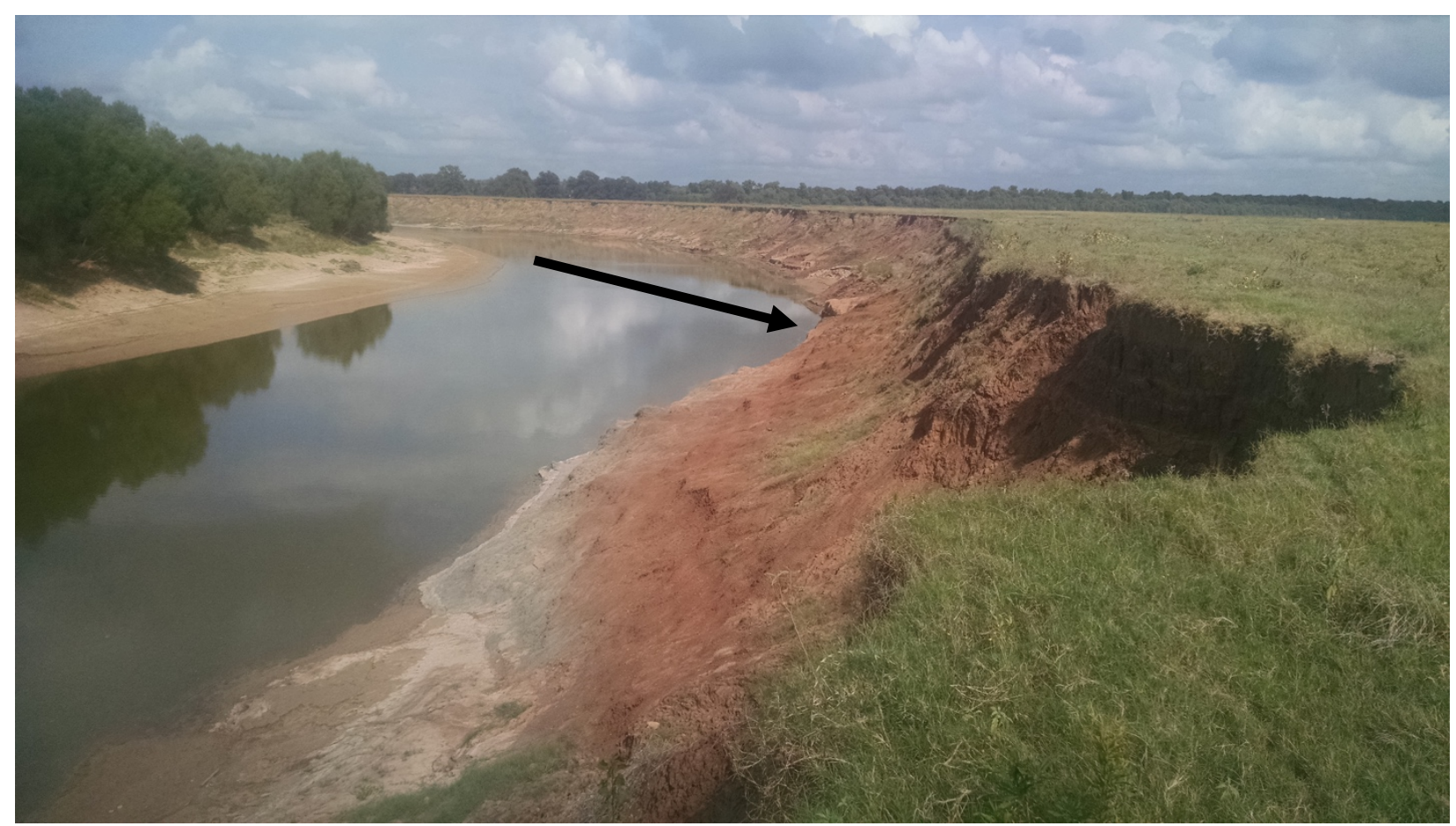

Figure 2.2. View of the Buffalo Ranch site (41BU119). Arrow points to location of the site at the base of the cutbank.

\section{Geologic Context}

At the Buffalo Ranch site, the late Quaternary stratigraphic sequence of the Brazos River is well exposed as defined by Waters and Nordt (1995). Here, Units I, II, III, IV, and IV are present (Figure 2.3).

Unit I lies at the base of the profile and consists of fine sand, capped by the A\&M paleosol. The paleosol is fine silty clay, with coarse subangular blocky structure. At the Buffalo Ranch site (41BU119) a mandible and several leg bone fragments of a camel (Camelops) were 
found in the sands below the A\&M paleosol. Elsewhere along the Brazos River, the sands below the paleosol have been dated to a maximum of $17,730 \pm 130{ }^{14} \mathrm{C}$ yr B.P (SMU-1754) or 21,673 to 21,529 cal yr B.P. (Waters and Nordt 1995). Waters and Nordt (1995) dated the A\&M paleosol to between $8390 \pm 330{ }^{14} \mathrm{C}$ yr B.P. $(\mathrm{GX}-15417)$ to $8465 \pm 100{ }^{14} \mathrm{C}$ yr B.P. (A-7513) or 9544 to 8795 cal yr B.P.

Unit II is a reddish brown sandy clay, with angular to subangular blocky structure and measures $5.75 \mathrm{~m}$ thick at the site. Calcium carbonate nodules and root casts were observed in this unit. Three radiocarbon ages from other outcrops of the Brazos River place this unit between $4185 \pm 55{ }^{14}$ C yr B.P. (A-7510) to $8145 \pm 75{ }^{14}$ C yr B.P. (A-7511), or 9242 to 4628 cal yr B.P. (Waters and Nordt 1995).

Unit III is primarily clay and is $2.25 \mathrm{~m}$ thick. It is capped by the Asa paleosol, a cumulic soil with a dark grey A horizon and wedge to coarse sub-angular structure (Waters and Nordt 1995). Four radiocarbon ages from this unit at other localities date between $880 \pm 50$ (A-6400) to $2505 \pm 75{ }^{14}$ C yr B.P. (GX-15415), or 2735 to 732 cal yr B.P. (Waters and Nordt 1995).

Unit IV overlies Unit III and consists of alternating beds of silt and clay that measures 2 $\mathrm{m}$ thick at the site. The weakly developed Katie paleosol caps the surface. Four wood samples from other Brazos River localities date this unit to between $430 \pm 70{ }^{14} \mathrm{C}$ yr B.P. (GX-15422) to $530 \pm 70{ }^{14}$ C yr B.P. (GX-15416), or 634 to $331 \mathrm{cal}$ yr B.P. (Waters and Nordt 1995).

Unit $\mathrm{V}$ is a thin layer of silt capping the Katie paleosol that measures $0.5 \mathrm{~m}$ thick at the site and dates to the historic time period (Waters and Nordt 1995). 


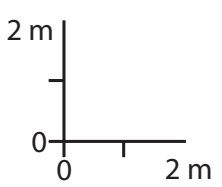

Excavation Block

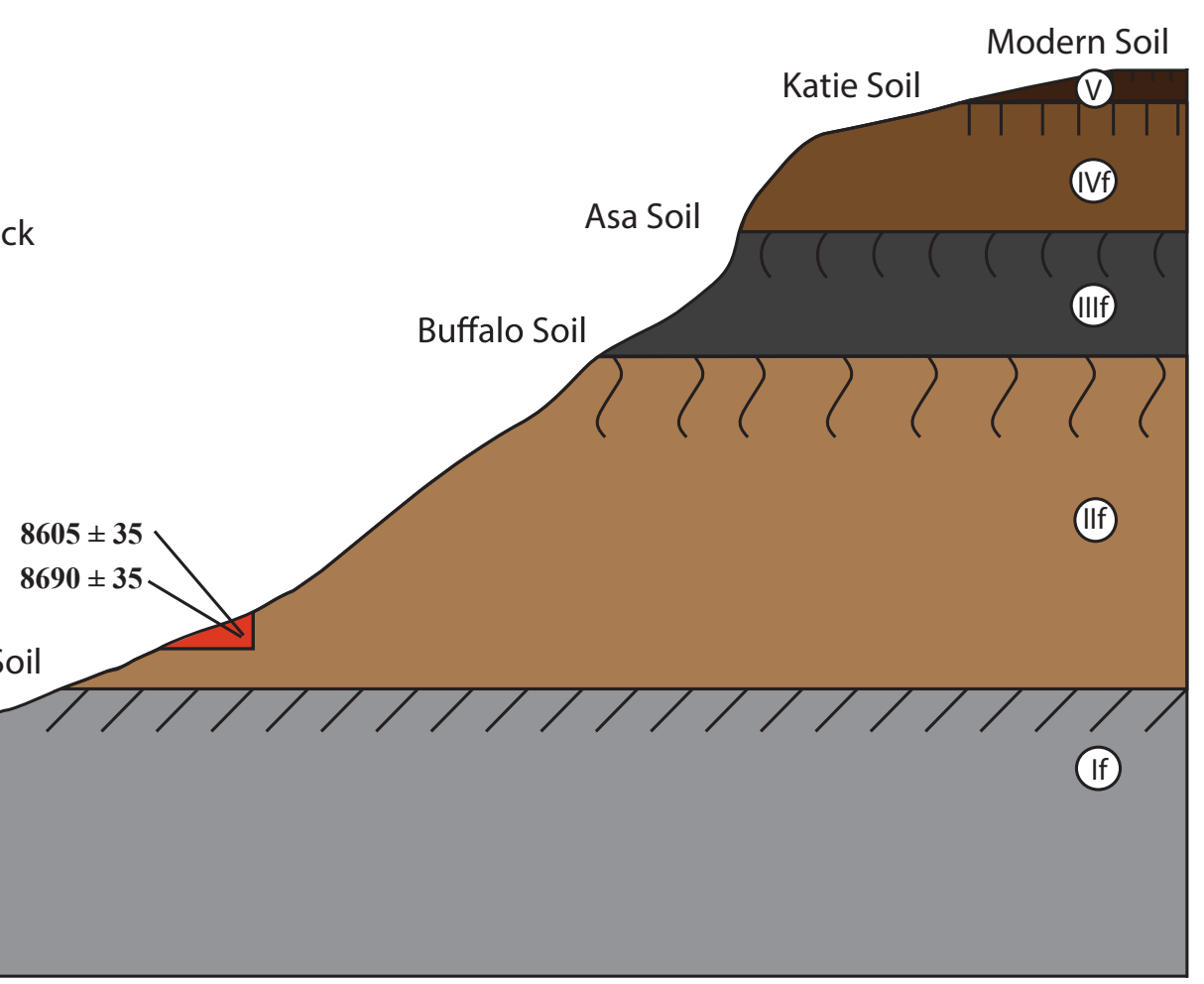

Figure 2.3. Geologic profile of the Buffalo Ranch site (41BU119).

The Buffalo Ranch site is located at the base of Unit II, about one meter above contact with Unit I. Artifacts were exposed over a distance of $8 \mathrm{~m}$. Here, a Wilson and a Big Sandy projectile point were found along with other artifacts eroding from a silty sand deposit that formed a prehistoric natural levee. Previous radiocarbon ages for geologic units I and II (Waters and Nordt 1995) bracket the age of this site between 9545-9325 cal yr B.P. (age for upper portion of Unit I) and 9240-9005 cal yr B.P. (age for lower portion of Unit II). 


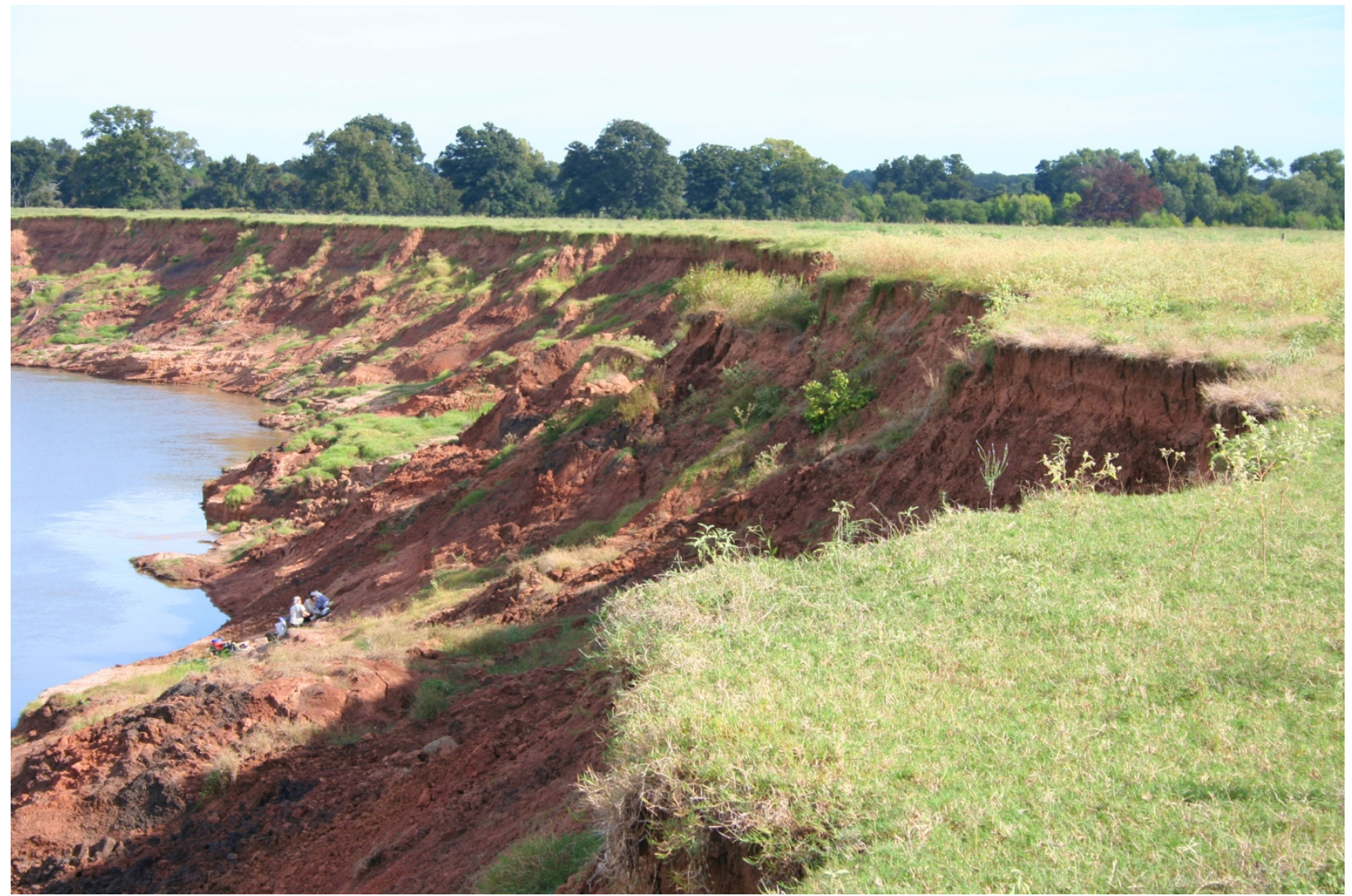

Figure 2.4. View of the Buffalo Ranch Site (41BU119) with crew excavating at the $2 \times 1 \mathrm{~m}$ unit.

Surface Collection of Cultural Materials at the Buffalo Ranch Site (41BU119)

One Wilson and one Big Sandy projectile point were found at the site. These points were found out of context by Michael Waters in 2012. Waters had determined (personal communication 2015) that these points eroded from the base of Unit II, in a zone with other artifacts. 


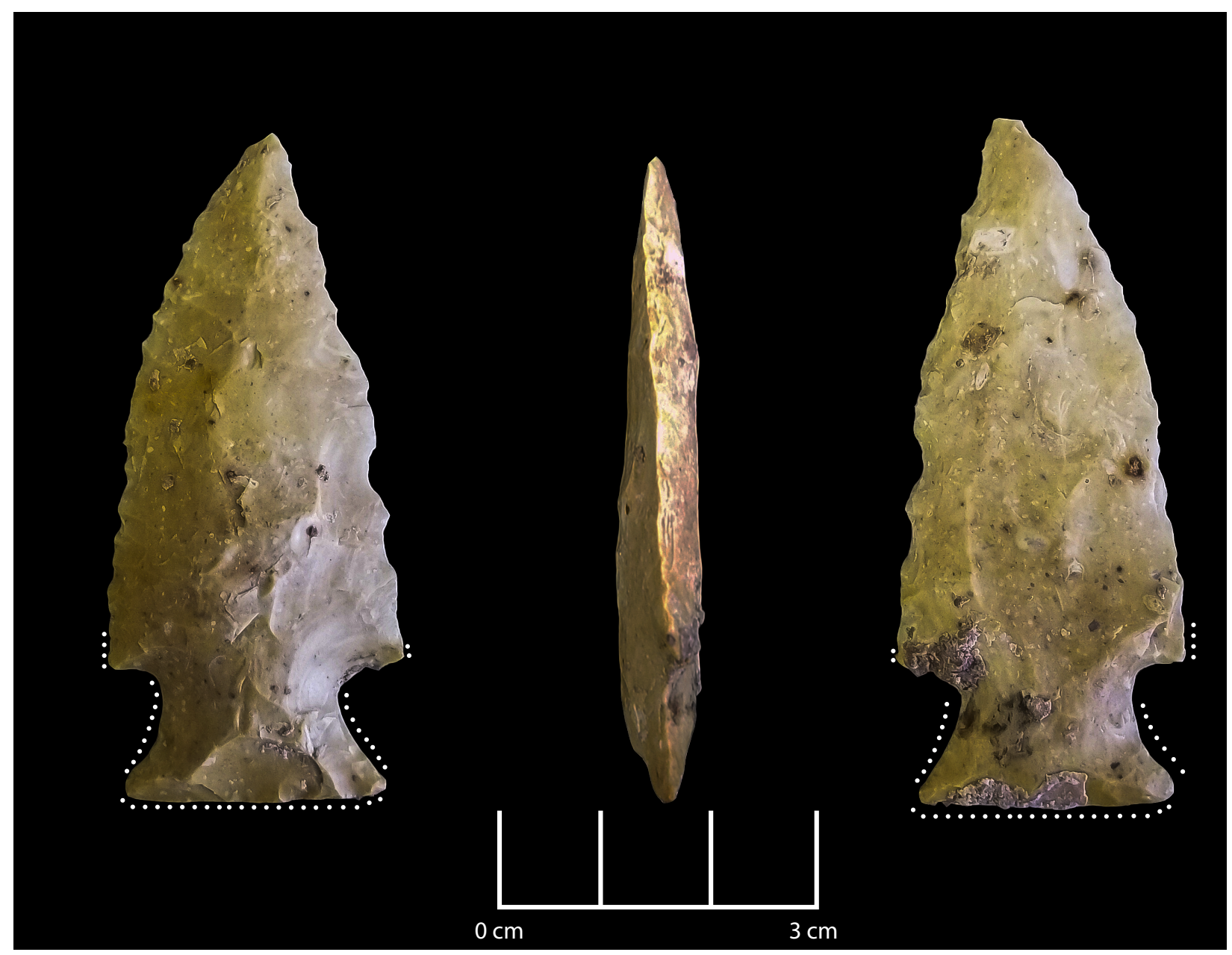

Figure 2.5. Wilson projectile point found at the Buffalo Ranch site (41BU119). Dots indicate areas of grinding.

The Wilson projectile point is made of Edwards chert. The blade is bifacially worked, with random flaking patterns along both sides. The haft element contains corner notches with a wide expanding stem. The stem leading to the corner notches are ground along each edge, with some grinding past the corner notch (Figure 2.5). Maximum length of the point measures 62.4 $\mathrm{mm}$, maximum thickness is $8.0 \mathrm{~mm}$, maximum width of the blade is $26.1 \mathrm{~mm}$, and maximum width of the stem is $22.8 \mathrm{~mm}$. The mass of this projectile point is 12.2 grams. 


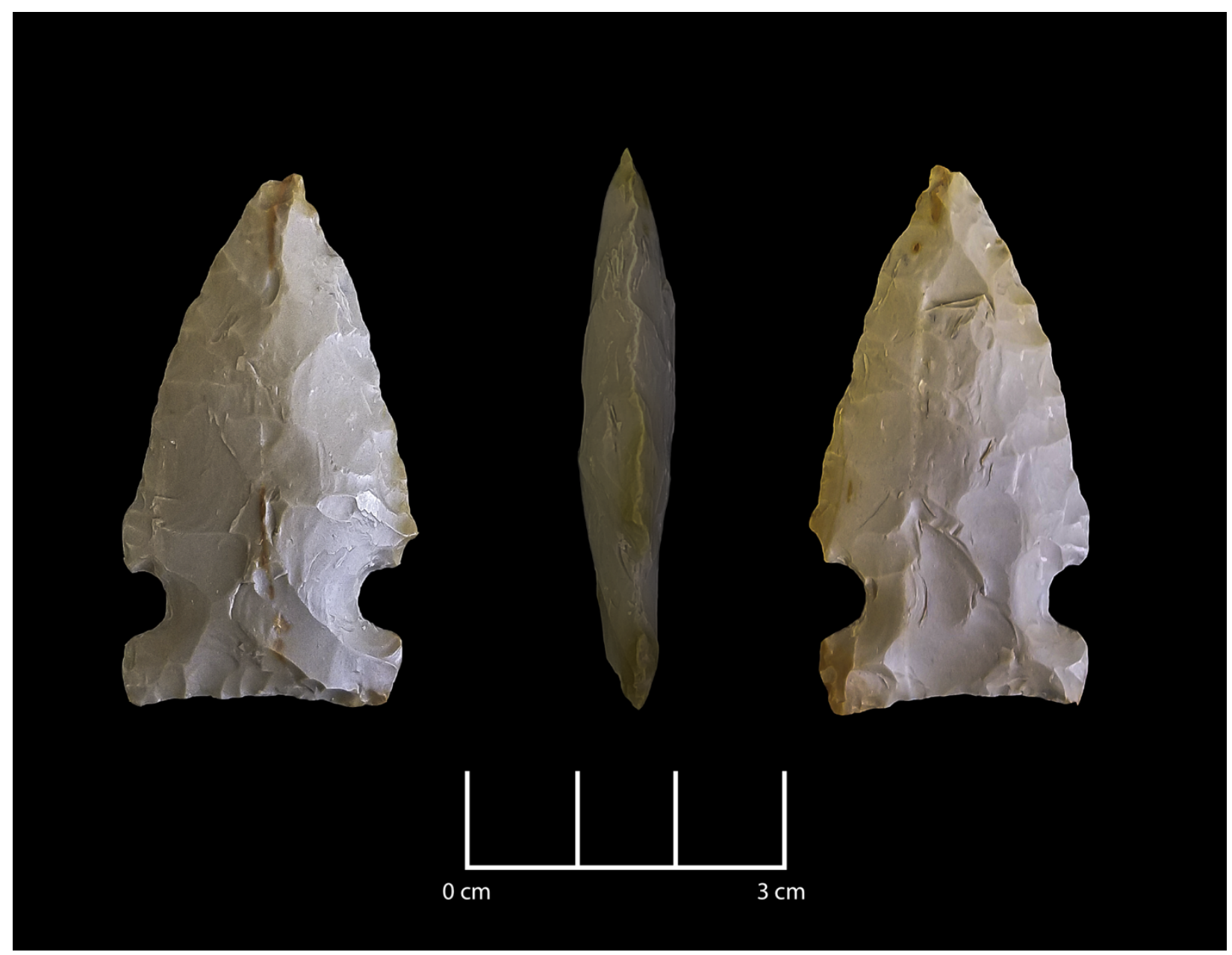

Figure 2.6. Big Sandy projectile point found at the Buffalo Ranch site (41BU119).

The Big Sandy projectile point is made of Edwards chert. This side-notched point has random flaking patterns along both faces of the blade. The haft element is a thick, squared base with no basal edge grinding present. Maximum length is $45.2 \mathrm{~mm}$, maximum thickness is 8.3 $\mathrm{mm}$, maximum width of the blade is $25.5 \mathrm{~mm}$, and maximum width of the stem is $24.4 \mathrm{~mm}$. The mass of this projectile point is 8.8 grams. 
Bousman (personal communication 2015) found fifteen flakes made of Edwards chert, two side scrapers made of chert, two cores made of petrified wood, one bone fragment, and one piece of fire-cracked rock from the surface of the archaeological horizon in 2014.

\section{Archaeological Investigation at the Buffalo Ranch Site (41BU119)}

At the site, I excavated a $2 \times 1 \mathrm{~m}$ unit into the bank exposure. Standard field methodologies were employed during the excavation. Units were excavated in four, $10 \mathrm{~cm}$ level increments and all sediments were screened through quarter inch mesh. The stratigraphic position of all lithic artifacts, bones, and radiocarbon samples found in situ were recorded.

In addition to the excavated materials, three additional artifacts were collected during my investigation in 2016. One biface thinning flake made of Edwards chert was found on the surface of the excavation unit. One core made of Edwards chert and one core made of petrified wood were found adjacent to the excavation unit that had recently eroded from the artifact-bearing deposit.

One core made of Edwards chert and two fire-cracked rocks with associated charcoal along with a burned bone fragment were found in situ during the excavation of the $2 \mathrm{x} 1 \mathrm{~m}$ unit (Figure 2.8). One normal flake and one modified flake were recovered while screening the sediment from the excavation area. Eight charcoal and one organic matter samples found in situ were also collected for dating. 


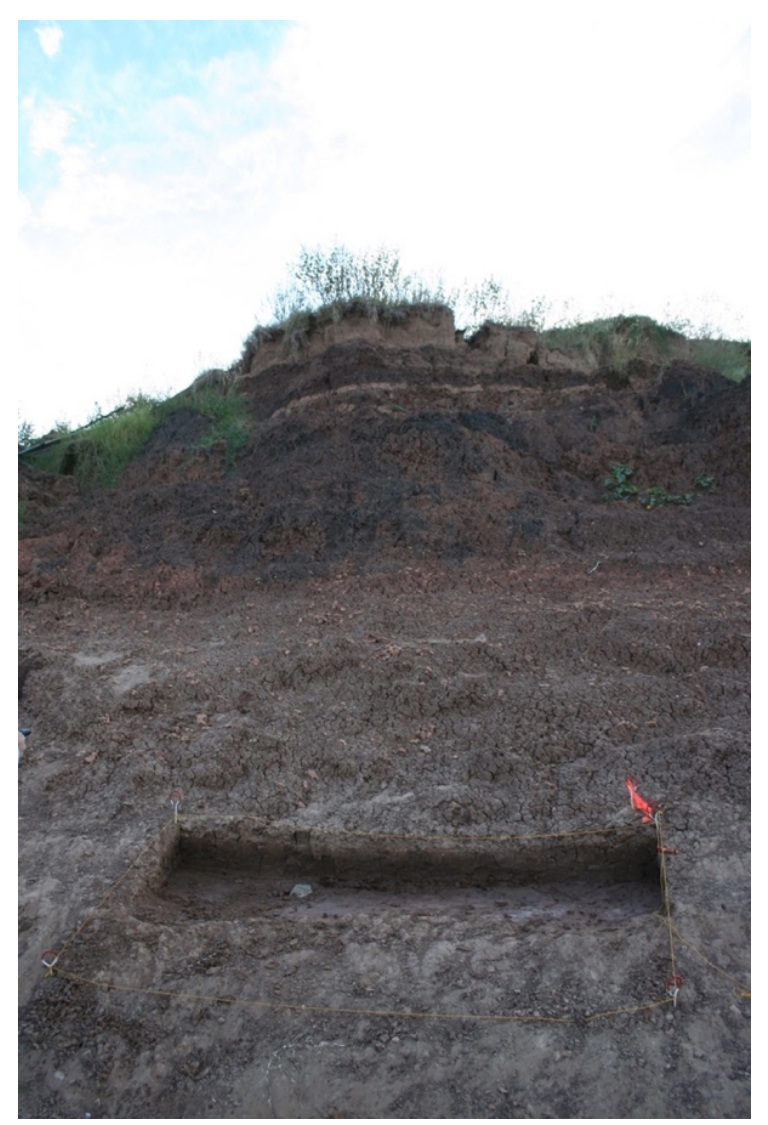

Figure 2.7. Excavation unit at the Buffalo Ranch site (41BU119).

The two pieces of fire-cracked rock were found $70 \mathrm{~cm}$ apart horizontally in the excavation unit (Figure 2.8). Charcoal samples found with the two fire-cracked rocks in close proximity to a burned bone suggest that a disturbed thermal feature may be close by. The lithic artifacts, burned bone, charcoal, and fire-cracked rocks all occur on a discrete surface with a relief of $7 \mathrm{~cm}$. This represents a single occupation surface. 


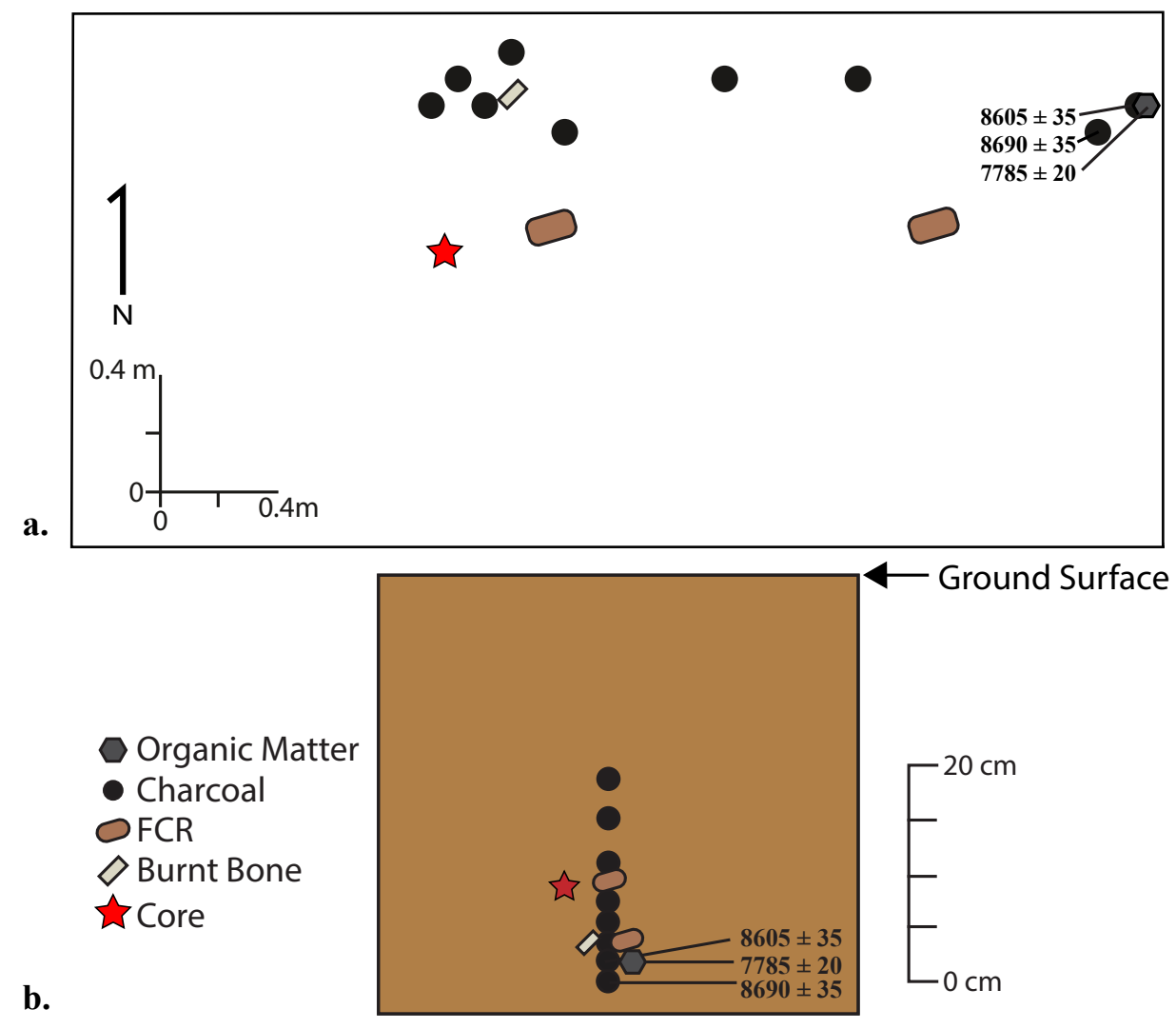

Figure 2.8. Artifact distribution at the Buffalo Ranch site (41BU119). a. Horizontal distribution of lithic artifacts, charcoal, organic matter, fire-cracked rock (FCR) and bone. b. Collapsed vertical distribution of lithic artifacts, charcoal, organic matter, bone, and fire-cracked rock found in the $2 \times 1 \mathrm{~m}$ unit.

\section{Radiocarbon Dating}

Two pieces of dispersed charcoal and one sample of organic matter were dated from the site (Table 3.3). The two charcoal samples yield ages of $8605 \pm 35{ }^{14} \mathrm{C}$ yr B.P. (UCIAMS180839) and $8690 \pm 35{ }^{14} \mathrm{C}$ yr B.P. (UCIAMS-180841), while the organic matter sample dates to $7785 \pm 20{ }^{14} \mathrm{C}$ yr B.P. (UCIAMS-180840). The two charcoal samples were located $40 \mathrm{~cm}$ northeast of the closest fire-cracked rock. One was at the same level as the fire-cracked rock and one was $2 \mathrm{~cm}$ below it (Figure 2.8). The two charcoal samples provide an average of $8648 \pm 25$ ${ }^{14} \mathrm{C}$ yr B.P. for the site. The calibrated age for this site is 9605 to 9545 cal yr B.P. 
The charcoal dates from the site correspond well with Waters and Nordt's (1995) ages for geologic units I (9545-9325 cal yr B.P.) and II (9240-9005 cal yr B.P.) that bracket the artifactbearing unit. However, UCIAMS-180840 provided a younger date compared to the two charcoal samples, even though the three samples were collected within $2 \mathrm{~cm}$ of each other (Table 2.1). The younger age is derived on what is likely humified organics and represents a minimum age for the deposit and associated artifacts. The most reliable ages for this archaeological horizon are provided by the two charcoal derived ages.

Table 2.1. Ages of radiocarbon samples from the Buffalo Ranch site (41BU119).

\begin{tabular}{|c|c|c|c|}
\hline Material Dated & Lab No. & ${ }^{14}$ C Age B.P. $( \pm 1 \sigma)$ & Calibrated Age cal yrs B.P. $( \pm 1 \sigma)^{1}$ \\
\hline Charcoal & UCIAMS-180839 & $8605 \pm 35$ & $9530-9583$ \\
\hline Organic Matter & UCIAMS-180840 & $7785 \pm 20$ & $8544-8588$ \\
\hline Charcoal & UCIAMS-180841 & $8690 \pm 35$ & $9560-9666$ \\
\hline
\end{tabular}

1. Ages calibrated using IntCal13 through Calib 7.0.4 (Stuvier and Reimer 1993; Reimer et. al 2013). 


\section{CHAPTER III}

\section{CONCLUSION}

The Buffalo Ranch site (41BU119) is the first locality in Texas and the American Southeast where Wilson and Big Sandy projectile points overlap in a buried geologic context. This site dates to between 9670 to $9530 \mathrm{cal}$ yr B.P. This age falls at the end of the transitional period defined by Bousman and Oksanen (2012), between 11,650 and 9050 cal yr B.P.

The dates for the Buffalo Ranch site (41BU119) overlap well with older ages for Big Sandy from Russell Cave; however, they appear too young compared to the ages for the Wilson zone at the Wilson-Leonard site. There is at least a 900 year difference between the youngest ages from Wilson-Leonard and the oldest possible age at the Buffalo Ranch site (41BU119).

Two alternative conclusions can be reached based on my data from the Buffalo Ranch site (41BU119). First, the Buffalo Ranch site (41BU119) is actually a Big Sandy component with an intrusive Wilson point. This point could have been brought to the site by people who made Big Sandy points. Second, the Big Sandy and Wilson points at Buffalo Ranch are in situ and Wilson extends later in time, at least 900 years beyond the ages defined at the Wilson-Leonard site. 


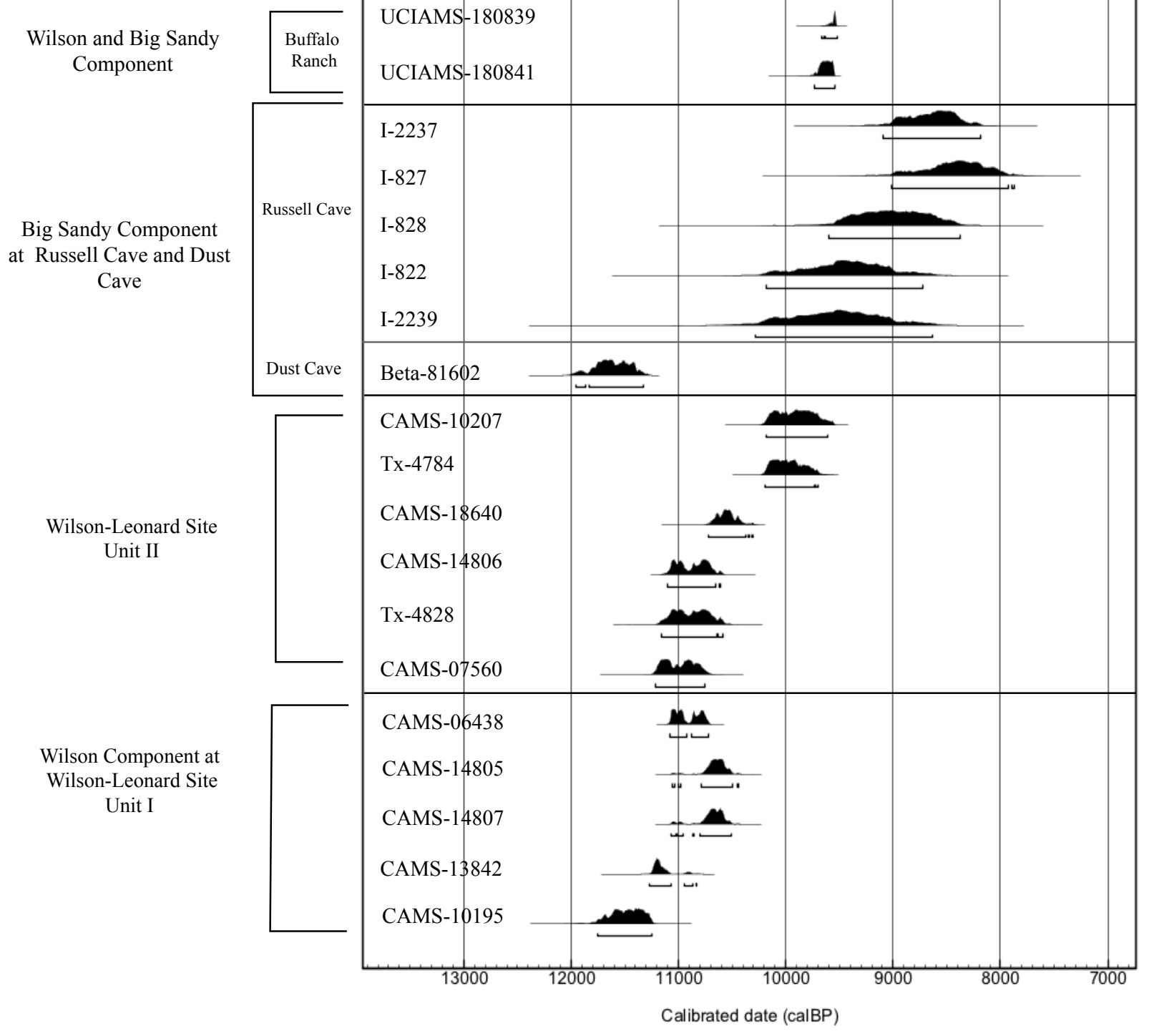

Figure 3.1. Calibrated Ages for the Wilson and Big Sandy component from Russell Cave, Dust Cave, and the Wilson-Leonard site compared to ages from the Buffalo Ranch site (41BU119). Model built using OxCal v4 3.2, IntCal 13 atmospheric curve (Bronk 2009; Reimer et. al 2013).

The radiocarbon ages from the Buffalo Ranch site agree well with the radiocarbon dates from Unit II at Wilson-Leonard (Figure 3.1). Nine Wilson and one Big Sandy projectile points were found together in Unit II. This may suggest that the Wilson and Big Sandy projectile points found in this unit are in situ, and represent either multiple archaeological components, or one single component. The older Paleoindian projectile points found in Unit II at Wilson-Leonard 
could be intrusive, brought to the site by Early Archaic people. The dates from Unit II at WilsonLeonard and my ages from the Buffalo Ranch site (41BU119) may reflect the latest occurrence of Wilson projectile points in the transitional period, extending beyond the Late Paleoindian subperiod and into the Early Archaic.

Overall, more transitional sites containing Wilson and Big Sandy projectile points are needed to provide further detail about this period and to learn more about human adaptations and changes that took place during the transition from the late Pleistocene to the early Holocene. 


\section{REFERENCES CITED}

Bronk Ramsey, C.

2009 Bayesian Analysis of Radiocarbon Dates. Radiocarbon 51(1):337-360.

Bousman, C. Britt, Michael B. Collins, Paul Goldberg, Thomas Stafford, Jan Guy, Barry W. Baker, D. Gentry Steele, Marvin Kay, Anne Kerr, Glen Fredlund, Phil Dering, Vance Holliday, Diane Wilson, Wulf Gose, Susan Dial, Paul Takac, Robin Balinsky, Marilyn Masson, and Joseph F. Powell.

2002 The Paleoindian-Archaic Transition in North America: New Evidence from Texas. American Antiquity 76:980-990.

Bousman, Britt C., Barry W. Baker, and Anne C. Kerr 2004 Paleoindian Archaeology in Texas. In The Prehistory of Texas, edited by Timothy K. Perttula, pp. 15-97. Texas A\&M University Press, College Station.

Bousman, Britt C., and Bradley J. Vierra 2012 Chronology, Environmental Setting, and Views of the Terminal Pleistocene and Early Holocene Cultural Transitions in North America. In From the Pleistocene to the Holocene: Human Organization and Cultural Transformations in Prehistoric North America, edited by Bradley J. Vierra and Britt C. Bousman, pp. 1-15. Texas A\&M University Press, College Station.

Bousman, Britt C., and Erik Oksanen

2012 The Protoarchaic in Central Texas and Surrounding Areas. In From the Pleistocene to the Holocene: Human Organization and Cultural Transformations in Prehistoric North America, edited by Bradley J. Vierra and Britt C. Bousman, pp. 197-232. Texas A\&M University Press, College Station.

Cambron, James W., and David C. Hulse 1975 Handbook of Alabama Archaeology: Part I, Point Types. The Archaeological Research Association of Alabama Inc.

Collins, Michael B. (editor) 1998 Wilson-Leonard: An 11,000-Year Archeological Record of Hunter-Gatherers in Central Texas (five volumes). Texas Archeological Research Laboratory, University of Texas at Austin. 
Crane H.R. and James B. Griffin

1965 University Of Michigan Radiocarbon Dates X. Radiocarbon 7:123-152.

DeJarnette, David L., Edward B. Kurjack, and James W. Cambron.

1962 Stanfield-Worley Bluff Shelter Excavations. Journal of Alabama Archaeology 8:1124.

Goodyear, Albert C.

1982 The Chronological Position of the Dalton Horizon in the Southeastern United States. American Antiquity 47:382-395.

Griffin, John W.

1974 Investigations in Russell Cave, Russell Cave National Monument, Alabama.

Publications in Archaeology (13) National Park Service. Washington D.C.

Johnson Jr, LeRoy

1962 Devil's Mouth Site: A Stratified Campsite at Amistad Reservoir, Val Verde County, Texas.

Justice, Noel D.

1987 Stone Age Spear and Arrow Points of the Midcontinental and Eastern United States. Indiana Univ. Pr, Bloomington.

Kneberg, Madeline.

1956 Some Important Projectile Point Types found in the Tennessee Area. Tennessee Archaeologist 12(1):17-28.

Patterson, Leland W., and J. Hudgins.

1985 Paleo-Indian occupations in Wharton County, Texas. Bulletin of the Texas Archeological Society 56:155-170.

Reimer, P.J., Bard, E., Bayliss, A., Beck, J.W., Blackwell, P.G., Bronk Ramsey, C., Buck, C.E., Cheng, H., Edwards, R.L., Friedrich, M., Grootes, P.M., Guilderson, T.P., Haflidason, H., Hajdas, I., Hatt' e, C., Heaton, T.J., Hoffmann, D.L., Hogg, A.G., Hughen, K.A., Kaiser, K.F., Kromer, B., Manning, S.W., Niu, M., Reimer, R.W., Richards, D.A., Scott, E.M., Southon, J.R., Staff, R.A., Turney, C.S.M., \& van der Plicht, J. 2013 IntCal13 and Marine13 Radiocarbon Age Calibration Curves 0-50,000 years cal B.P.. Radiocarbon, 55(4):1869-1887. 
Sherwood, Sarah C., Boyce N. Driskell, Asa R. Randall, and Scott C. Meeks 2004 Chronology and Stratigraphy at Dust Cave, Alabama. American Antiquity 69:533-554.

Sorrow, William M.

1968 The Devil's Mouth Site: The Third Season-1967. Papers of the Texas Archaeological Salvage Project (14). Austin, TX.

Stuvier, Minze and Paula J. Reimer.

1993 Extended 14 C Data Base and revised Calib 3.0 14 C Age Calibration Program. Radiocarbon 35(1):215-230.

Thulman, David K.

2017 Dust Cave Revisited: A Bayesian Reanalysis of the Radiocarbon Record. American Antiquity 82:168-182.

Waters, Michael R., and Lee C. Nordt. 1995 Late Quaternary Floodplain History of the Brazos River in East-Central Texas. Quaternary Research 43(3):311-9. 